\title{
Macro- and micro-scale study and chronology of Late Weichselian aeolian sediments in Estonia, north-eastern European Sand Belt
}

\author{
Edyta Kalińska ${ }^{1,2}$ (1) $\cdot$ Tiit Hang $^{2} \cdot$ Argo Jõeleht $^{2} \cdot$ Sander Olo $^{3} \cdot$ Māris Nartišs $^{4} \cdot$ Grzegorz Adamiec $^{5}$
}

Received: 7 September 2018 / Accepted: 13 June 2019 / Published online: 27 June 2019

(c) The Author(s) 2019

\begin{abstract}
Patchy aeolian landforms, representing the NE part of the European Sand Belt, occur in NE Estonia, between the Gulf of Finland and Lake Peipsi. The dunes are restricted to the former glacial lakebed, thus lying directly in contact with glaciolacustrine sediments, and have so far prompted different opinions regarding their genesis and age. This study aims to answer these open questions regarding the age and origin of these landforms and to provide information on the associated past sedimentary processes. To achieve this, we combine macro-scale (sedimentary structures and ground-penetrating radar survey) and micro-scale (grain-size, shape and character of quartz grain surfaces and mineral composition) studies with optically stimulated luminescence dating. The glaciolacustrine fines in the study area are wavy stratified, with the occurrence of mica horizons and prevalence of quartz sand grains with aeolian characteristics. Therefore, these sediments argue for near-standing/low-energy water conditions in the glacial lake, where allochthonous material was delivered by wind. A fall in the lake level and the occurrence of dry land on the northern coast of the regressive Late Weichselian Lake Peipsi favoured aeolian activity from ca. 13.5 to $10.5 \mathrm{ka}$ in the region. The aeolian accumulation was brief-as apparent from the results of the micro-scale study - and lacks evidence of sediment recycling. Only easily-removable mica was deflated at the end of the aeolian depositional phase. Aeolian activity terminated ca. $10.5 \mathrm{ka}$ due to a rising groundwater level that is apparent from the onset of paludification in the region.
\end{abstract}

Keywords Dune $\cdot$ Aeolian sediments · Grain size $\cdot$ Quartz grain surfaces $\cdot$ Mineral composition $\cdot$ Optically stimulated luminescence dating $\cdot$ European Sand Belt $\cdot$ Estonia

\section{Introduction}

Electronic supplementary material The online version of this article (https://doi.org/10.1007/s00531-019-01746-2) contains supplementary material, which is available to authorized users.

Edyta Kalińska

edyta.kalinska@umk.pl

1 Faculty of Earth Sciences, Nicolaus Copernicus University, Lwowska 1, 87-100 Toruń, Poland

2 Institute of Ecology and Earth Sciences, University of Tartu, Ravila 14A, 50411 Tartu, Estonia

3 Department of Geology, Estonian Museum of Natural History, Lai 29A, 10133 Tallinn, Estonia

4 Faculty of Geography and Earth Sciences, University of Latvia, Jelgavas 1, Riga 1004, Latvia

5 Division of Radioisotopes, Institute of Physics-Centre for Science and Education, Silesian University of Technology, Konarskiego 22B, 44-100 Gliwice, Poland
Dunes, coversands and loess covers occur abundantly in the European lowlands and are important elements of the European Sand Belt (ESB; Koster 1988, 2009). These landforms and sediments formed during glacial events, when a decrease in precipitation, a scarcity of vegetation, and increasing wind speeds and frost abrasion resulted in a large amount of material being deposited from off the Scandinavian Ice Sheet (SIS) (Bertran et al. 2016).

While the western and central parts of this belt have been studied in some detail (Ujházy et al. 2003; Koster 2005; Bateman and Murton 2006; Kasse et al. 2007; Derese et al. 2009; Tolksdorf et al. 2010; Bertran et al. 2013, 2014; Vandenberghe et al. 2013; Obreht et al. 2015; Zieliński et al. 2015), its NE part has so far gained relatively little attention (Drenova et al. 1997; Zeeberg 1998; Kalińska-Nartiša et al. 2015a, b, 2016). This part of the belt is located entirely inside the maximum extent of the SIS, the sedimentary cover 


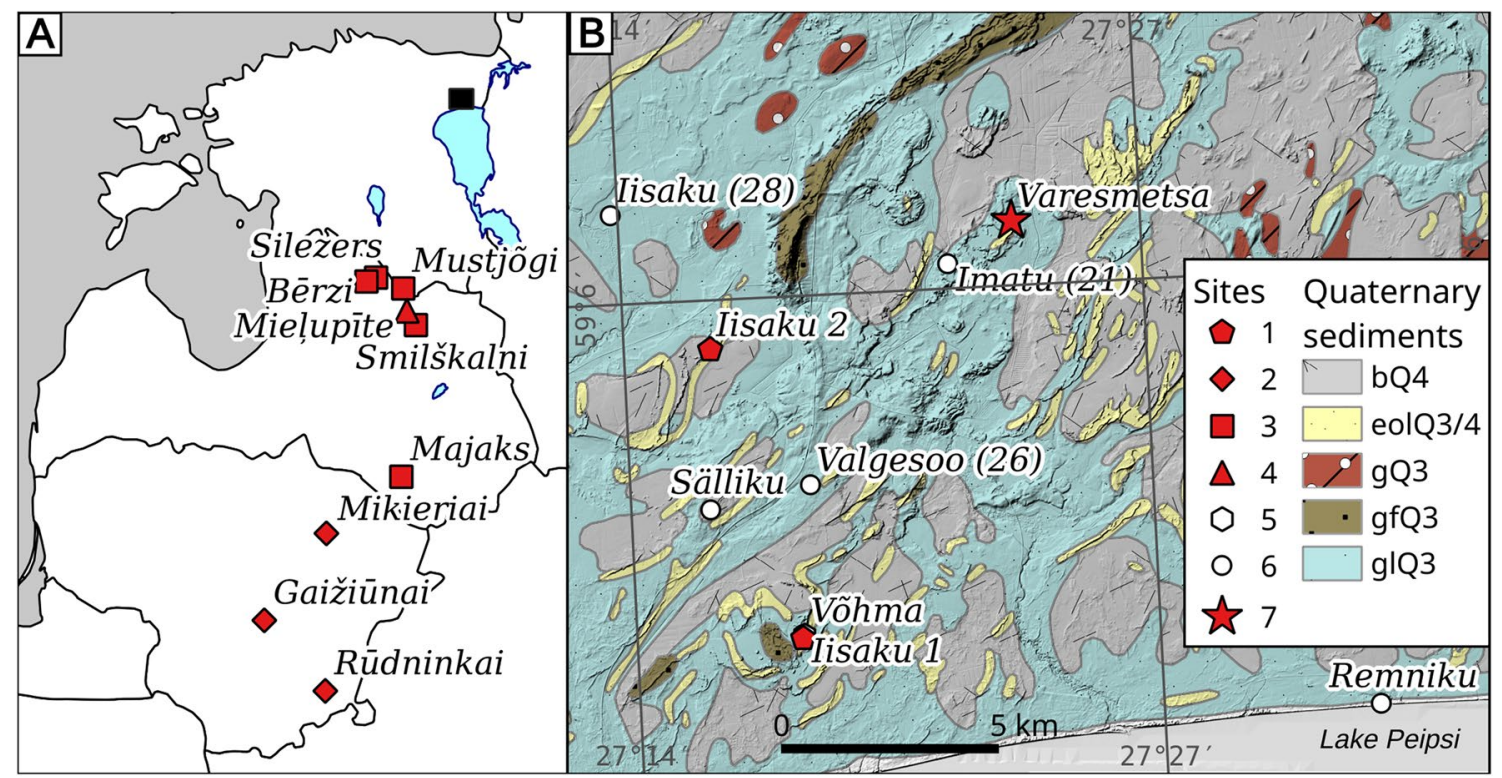

Fig. 1 Location of the investigated site (Varesmetsa) and other sites with luminescence age determinations used in the text. Location of b is shown in a with a black square. Sites: 1-Kalińska-Nartiša et al. (2015a); 2-Kalińska-Nartiša et al. (2015b); 3-Kalińska-Nartiša et al. (2016); 4-Nartišs and Kalińska-Nartiša (2017); 5-Ratas

is patchy (Zeeberg 1993, 1998) and is restricted to basins within glacial lakebeds, outwash fans or glaciofluvial terraces (Guobytė and Satkūnas 2011). This is why aeolian landforms there differ from the largely continuous dunefields and coversands of Western-Central Europe, rather resembling the more scattered landforms found in Sweden (Alexanderson and Bernhardson 2016) and Finland (Käyhkö et al. 1999).

In this study, we focus on the patchy aeolian landforms between the Gulf of Finland and Lake Peipsi in NE Estonia. The dune area is entirely limited to the basin of a former glacial lakebed (Glacial Lake Peipsi), and thus might be expected to lie directly next to sediments of glaciolacustrine origin. The dunes in this region have already gained some attention (Raukas and Hütt 1988; Zeeberg 1998; Raukas 2011; Kalińska-Nartiša et al. 2015a; Ratas et al. 2015). However, different opinions exist regarding the genesis and age of these landforms. A morphological study by Rähni (1954) concluded with an inland dune theory, with the timing of formation being during the Younger Dryas cold period (Raukas et al. 1971). Kajak (1963) described the dunes as ancient coastal formations of Glacial Lake Peipsi. Raukas and Hütt (1988) and Karukäpp and Raukas (1999) considered these forms to be repeatedly reblown/reworked glaciolacustrine kames or crevasse fillings, respectively. Zeeberg (1998) and Kalińska-Nartiša et al. (2015a) placed these aeolian landforms into a wider context, describing them as part of the ESB. These numerous interpretations were developed et al. (2015); 6-Raukas and Hütt (1988); 7-this study. Quaternary sediment cover (according to Mardla 1967): bQ4-peat; eolQ3/4aeolian sands; gQ3 - glacial sediments; gfQ3-glaciofluvial sand and gravel; glQ3-glaciolacustrine sands. Digital terrain model for shaded relief-Estonian Land Board (2013)

from the facts that: (1) the principal internal architectures of landforms and substratum-dune governance had been largely unexplored, and (2) sedimentary data had been limited to only a few outcrops. The emphasis of this study is, therefore, placed on the Varesmetsa site, NE Estonia (Fig. 1), which is one of the few open sections presenting an aeolian succession with underlying glaciolacustrine fines. We use a multiproxy approach to study the substratum and dune sediment structures in outcrop and via ground-penetrating radar (GPR) (macro-scale study), alongside sediment properties, such as grain size, the shape and character of quartz grain surfaces, and the overall mineral composition (microscale study), to obtain more details about the possible source and distance of the aeolian transport. Several samples are also dated by a luminescence technique to contribute to the discussion about the correlation and timing of the aeolian activity in this area of the ESB. We additionally focus on adjacent landforms and their sediments, particularly in terms of landform internal architecture and sediment grain-size variation. The latter are complementary data from previous work at the Iisaku sites in this area (Kalińska-Nartiša et al. 2015a; Fig. 1). This combination of macro- and micro-scale studies of the past depositional conditions help us to address the open research questions regarding the age and genesis of these landforms. The new data provides information on the past sedimentary processes and palaeoenvironmental trends in the region, and help to correlate these forms with similar deposits in Europe. 


\section{Location and geological setting}

A cross-section of the Varesmetsa dune was available during a 2011 fieldwork season in NE Estonia, north of Lake Peipsi, ca. $8 \mathrm{~km}$ east of the town of Iisaku. Two complementary Iisaku $(1,2)$ sites, also discussed herein, are located south of this town (Fig. 1). The investigated dune area lies outside of the deglacial Pandivere-Neva ice marginal zone of the Late Weichselian glaciation (Kalm 2006; Kalm et al. 2011), at a distance of only a few kilometres from the Iisaku-Illuka esker ridges. Indirect accelerator mass spectrometry radiocarbon (AMS ${ }^{14} \mathrm{C}$ ) ages positioned the Pandivere-Neva stadial in northern Estonia at 14,000-13,800 cal year BP (Amon et al. 2016). Varve chronology and a magnetostratigraphic study of the Pärnu area, western Estonia, placed the stagnation of the ice margin at the Pandivere-Neva line at ca. 13.9-13.8 ka BP (Hang et al. 2011).

The sediment cover in the environs of Varesmetsa consists of aeolian and peat series directly overlying the glaciolacustrine sediments of Glacial Lake Peipsi, which correlate with a Pandivere age (Hang 2001, 2003). The most outstanding glacial landforms are the aforementioned Iisaku-Illuka esker ridges, which bound the study area to the NW. These are up to $40 \mathrm{~m}$ high and are NE-SWoriented parallel ridges consisting of pebbly gravel with boulders in the SW and gravelly sand in the NE part of the ridge system. Other features in the study area are 8-15 m high, rounded, plateau-like glaciolacustrine kames, individually occupying ca. $1-5 \mathrm{~km}^{2}$ footprints and possessing steep $\left(25^{\circ}\right)$ slopes. The kames mostly consist of laminated fine sand and silt.

A group of ca. $200 \mathrm{NE}-\mathrm{SW}$-aligned ridge-like and parabolic dunes, with lengths of $0.15-3.3 \mathrm{~km}$, widths from 20 to $120 \mathrm{~m}$ and heights of up to $10-15 \mathrm{~m}$ prevail in an area of ca. $50 \mathrm{~km}^{2}$. These landforms are covered by pine forests and are predominantly surrounded by vast wetlands, with up to a $10 \mathrm{~m}$ thick peat cover. The landform orientations and $3^{\circ}-18^{\circ}$-slanting concave windward slopes reveal a W-NW palaeowind direction (Zeeberg 1998).

The studied Varesmetsa dune is located in the NW part of the dune field, standing apart from the largest group of dunes a few $\mathrm{km}$ to the NE and the Iisaku-Illuka esker ridges at $4-5 \mathrm{~km}$ to the $\mathrm{W}-\mathrm{NW}$. The dune is ca. $800 \mathrm{~m}$ long, 50-120 m wide, and its relative height reaches $8 \mathrm{~m}$ (Fig. 2a, b). With its NE-SW orientation, it crosses one of the plateau-like kames (Fig. 2c). This is why the altitude of the dune foot varies from 45 to $51 \mathrm{~m}$ a.s.l., while the relative height of the landform is relatively stable. The highest point of the dune is at an altitude of $59.8 \mathrm{~m}$ a.s.l. The $9^{\circ}-11^{\circ}$-slanting windward slope faces NW and is more indented compared to the straight and steeper, $18^{\circ}-21^{\circ}$-slanting leeward slope, towards the SE. From here on, we use the terms 'Aeolian 1' and 'Aeolian 2 ' for the sequences of sediments on the windward and leeward slopes, respectively. The cross-section of the dune was located in its northern part $\left(59^{\circ} 6^{\prime} 52^{\prime \prime} \mathrm{N}, 27^{\circ} 23^{\prime} 51^{\prime \prime} \mathrm{E}\right.$; Fig. 1), and was $120 \mathrm{~m}$ long and up to $9 \mathrm{~m}$ high, with the section opening towards the north. Glaciolacustrine fines (Glaciolacustrine sequence), as the substrate, were exposed in the NW peripheral part of the section, while inclined-low (Aeolian 1) and high (Aeolian 2) - stratifications of aeolian sands were exposed in the main part of the outcrop (Table 1; Fig. 2). Complementary to the Varesmetsa site are the Iisaku $(1,2)$ sites, which have already gained some attention (Kalińska-Nartiša et al. 2015a), but were also considered in this study (see "Methodology"). The dune-foot altitude at these sites varies between 45 and $48 \mathrm{~m}$ a.s.l., and their crests reach an altitude of 49.3 (Iisaku 1) and 58.9 (Iisaku 2) $\mathrm{m}$ a.s.l., thus being similar to the Varesmetsa dune. Mostly, tabular cross- and lowangled inclined stratification occurs at Iisaku 1, with largescale inclined stratification at Iisaku 2 (Kalińska-Nartiša et al. 2015a).

\section{Earlier sediment age determinations}

Several attempts at determining the aeolian chronology have already been made for the study area (see Supplementary Table S1 for details). For example, thermoluminescence (TL) and infrared optically stimulated luminescence (IRSL) age determinations have obtained a range of $13.6 \pm 1.5$ to $3.0 \pm 0.5 \mathrm{ka}$ (Raukas and Hütt 1988). However, of these ages, only those between $4.0 \pm 0.5$ and $7.1 \pm 0.7 \mathrm{ka}$ were considered to be reliable, due to the age-depth inversion (Raukas 1999, 2011).

A more recent set of ages cluster into four groups (Supplementary Table S1): (1) $13.3 \pm 1.2 \mathrm{ka}$; (2) between 12.7 \pm 0.8 and $12.5 \pm 0.8 \mathrm{ka}$; (3) between $11.5 \pm 0.7$ and 10.9 $\pm 0.8 \mathrm{ka}$; and (4) $10.5 \pm 0.7 \mathrm{ka}$. These were obtained using post-infrared pulsed blue OSL (Kalińska-Nartiša et al. 2015a). A relatively new study by Ratas et al. (2015) placed the dune formation in this area at about $8 \mathrm{ka}$, according to a single OSL age; however, no details regarding the date and sample laboratory treatment were provided.

\section{Methodology}

\section{Ground-penetrating radar (GPR) survey}

The internal structure of the Varesmetsa dune ridge was studied using a GPR device (Zond 12e, Radar Systems Inc., Latvia). A $300 \mathrm{MHz}$ antenna was pulled across and along the 


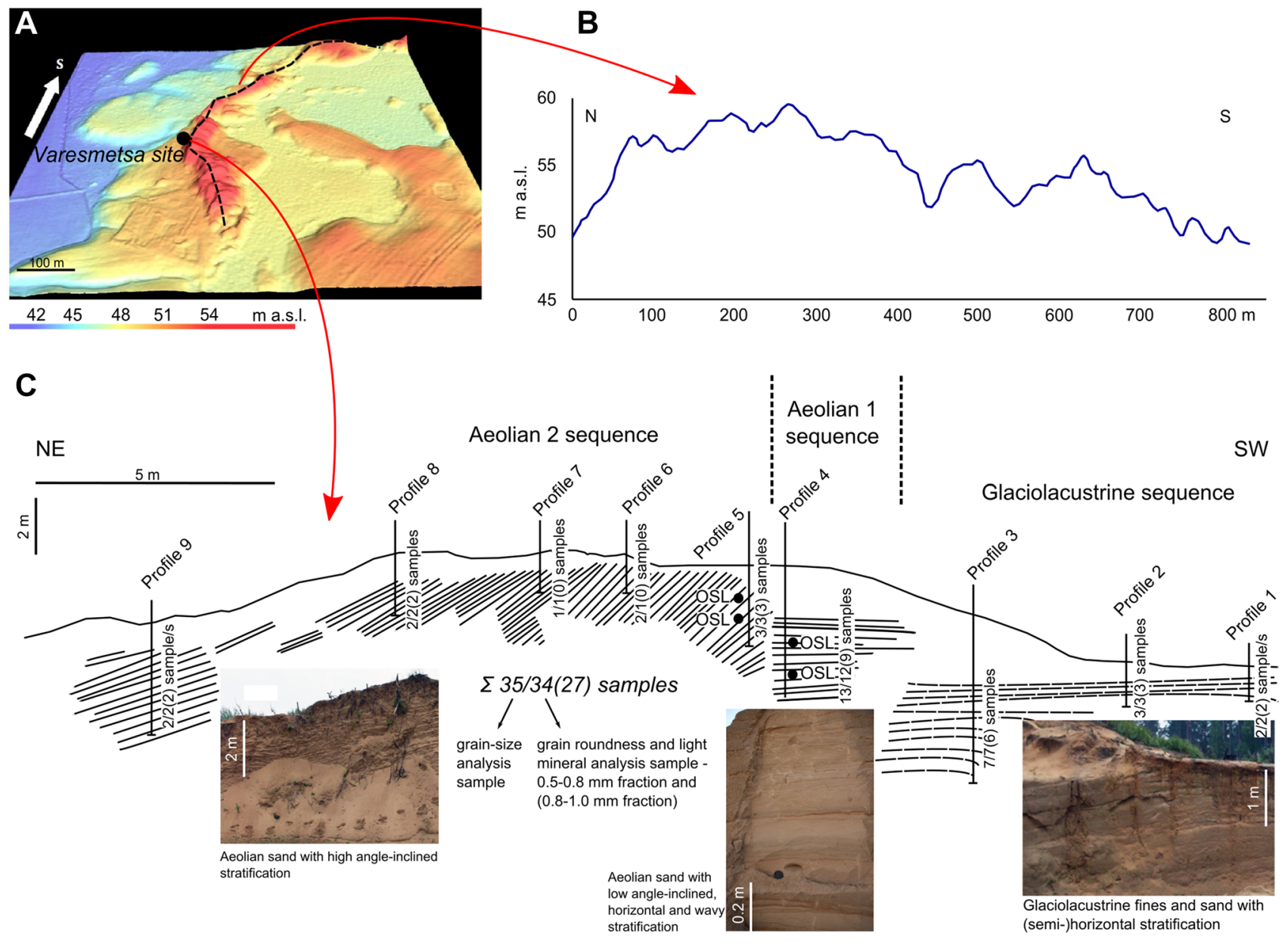

Fig. 2 a Elevation model of the Varesmetsa dune and its surroundings (based on the LiDAR data from Estonian Land Board), b longitudinal profile of the Varesmetsa dune, $\mathbf{c}$ cross-section of dune at the Varesmetsa site with investigated profiles and samples distribution

Table 1 Details about sediment sequences as distinguished at Varesmetsa

\begin{tabular}{llll}
\hline Sediment sequences & Profile number & Sediment description & Type of deposition \\
\hline Glaciolacustrine & $1-3$ & Sub-horizontally laminated fines and sands & Low-energy water conditions \\
Aeolian 1 & 4 & Sand with low-angle inclined stratification & Windward slope \\
Aeolian 2 & $5-9$ & Sand with high-angle inclined stratification & Leeward slope \\
\hline
\end{tabular}

ridge, and measurements were triggered at $0.1 \mathrm{~m}$ intervals by the odometer wheel. The profiles were positioned with a GPS device (usually with an accuracy of better than $10 \mathrm{~m}$ in forested areas) that was attached to the GPR. The profiles were corrected for topography, using the profile coordinates and LiDAR data (Estonian Land Board).

The data were processed using Prism 2 software. The conversion of the time-scale to a depth-scale required information about the electromagnetic wave velocities (or relative dielectric permittivity, $\varepsilon$ ) in the soils. The velocities were deduced using a hyperbolic curve fitting technique, although the number of point sources (e.g. rocks) in these generally fine-grained sediments was low. An dielectric permittivity of $\varepsilon=8$ was used for the ridge above the water table and $\varepsilon=20$ for the saturated fines. These values are consistent with relatively wet conditions, such as peatlands, in the environs of Varesmetsa dune. The profiling was conducted in November.

\section{Sampling}

A total of 35 samples were collected from the cross-section of Varesmetsa dune $\left(59^{\circ} 6^{\prime} 52.81^{\prime \prime} \mathrm{N}, 2^{\circ} 23^{\prime} 51.25^{\prime \prime} \mathrm{E}\right.$; Fig. 2c) for grain-size analysis, each weighing 1-1.5 kg wet. Three sediment sequences, comprising nine profiles, were sampled: 
the Glaciolacustrine (Profiles 1-3), Aeolian 1 (Profile 4) and Aeolian 2 (Profiles 5-9), as shown in Fig. 2 and Table 1. The Glaciolacustrine sequence represents the subhorizontallylaminated glaciolacustrine fines and sands. The Aeolian 1 sequence documents aeolian sand with low-angled inclined stratification, modified by horizontal and wavy stratification. The Aeolian 2 sequence consists of sand with high-angled inclined stratification. Samples along the profiles were collected vertically at 10-30 cm intervals (Fig. 2c).

In addition, 82 grain-size analyses were performed on Iisaku site samples ( 36 from Iisaku 1 and 46 from Iisaku 2; $59^{\circ} 1^{\prime} 47.21^{\prime \prime} \mathrm{N}, 27^{\circ} 18^{\prime} 24.47^{\prime \prime} \mathrm{E}$ and $59^{\circ} 5^{\prime} 23.29^{\prime \prime} \mathrm{N}$, $27^{\circ} 16^{\prime} 30.41^{\prime \prime} \mathrm{E}$, respectively; Fig. 1). Those results are presented here, together with the textural sedimentary features (Kalińska-Nartiša et al. 2015a), for regional comparison.

\section{Micro-scale analyses}

The samples for grain-size analysis were oven-dried at $105^{\circ} \mathrm{C}$, subsampled in $100-150 \mathrm{~g}$ aliquots, and mechanically sieved for 20 min. Logarithmic (Folk and Ward 1957) graphical measurements, such as mean, sorting $(\sigma)$ and skewness were calculated using GRADISTAT software (Blott and Pye 2001). Grain-size data are presented as cumulative and bivariate plots of graphical measures, which can help in distinguishing different types of deposition (Clarke et al. 2014).

The quartz grains of the $0.5-0.8 \mathrm{~mm}$ and $0.8-1.0 \mathrm{~mm}$ sieved fractions were used for both grain roundness and grain surface (matte/shiny) analysis, which was performed under a binocular microscope. These fractions have been considered to be the most suitable for studying aeolian abrasion (Cailleux 1942; Mycielska-Dowgiałło 1993) because finer fractions may have a limited ability to record aeolian processes (Kalinska-Nartiša et al. 2017a, b; Kalińska-Nartiša and Gałka 2018). In this study, 33 and 27 samples of the $0.5-0.8 \mathrm{~mm}$ and $0.8-1.0 \mathrm{~mm}$ fractions, respectively, were analysed. From these, 120-150 quartz grains were randomly chosen at $40 \times$ magnification. Using the classification of grain shapes and surfaces of Cailleux (1942), modified by Mycielska-Dowgiałło and Woronko (1998), six groups of grains were visually determined: (1) well rounded and matte across the whole surface; (2) partially rounded and matte only on the most convex part of the grain; (3) well rounded with a shiny surface; (4) partially rounded with a shiny surface; (5) intensively weathered by silica precipitation; and (6) broken, but with preservation of at least $30 \%$ of the original grain surface. These grain categories are representative of aspects of the sedimentary environment (for details, see Woronko et al. 2015).

A total of 34 and 27 samples from $0.5-0.8$ and $0.8-1.0 \mathrm{~mm}$ fractions, respectively, were examined by light mineral analysis (Woronko et al. 2013). Of particular interest were quartz, feldspar and mica, due to their differential resistance to reworking/redeposition (Muhs 2004; Woronko et al. 2013). In this study, 200-220 grains from each sample were randomly selected and categorised as quartz, feldspar, crystalline rock particles and mica.

\section{Luminescence dating}

Four samples were collected for OSL dating from the aeolian sediments of Profile 4 (Aeolian 1 sequence) from depths of $2.40 \mathrm{~m}$ and $2.70 \mathrm{~m}$, and from Profile 5 (Aeolian 2 sequence) from depths of 1.60 and $1.80 \mathrm{~m}$, adjacent to where the textural samples were taken from (Table 1). In the field, 0.5-m-long opaque PVC tubes were hammered into freshly dug and cleaned surfaces of the pit. The tubes were opened in the laboratory (Silesian University of Technology, Gliwice Centre for Absolute Dating, Gliwice, Poland), and the samples were exposed to subdued orange light.

For the OSL measurements, coarse grains of quartz (90-125 $\mu \mathrm{m})$ were used. Extraction of these from the sediment samples involved treatment with $20 \%$ hydrochloric acid and 20\% hydrogen peroxide The samples were then wet-sieved and the quartz was obtained using sodium polytungstate solutions to concentrate grains with densities in the range of $2.62-2.75 \mathrm{~g} / \mathrm{cm}^{3}$. Etching in concentrated hydrofluoric acid for $60 \mathrm{~min}$ was performed to clean the outer surfaces of the grains and to remove the contribution of external alpha radiation and possible contamination from feldspar. The beta-dose attenuation was calculated using Mejdahl (1979).

To estimate the annual dose, high-resolution gamma-ray spectrometry, using a Canberra HPGe detector, was applied. On arrival in the laboratory, the natural water content in the samples was measured, and they were then dried. The samples were stored for 3 weeks prior to measurement to ensure equilibrium between the gaseous ${ }^{222} \mathrm{Rn}$ and ${ }^{226} \mathrm{Ra}$ in the ${ }^{238} \mathrm{U}$ decay chain. Each measurement lasted for at least $24 \mathrm{~h}$. The activities of the isotopes present in the sediment were determined using the International Atomic Energy Agency (IAEA) standards RGU, RGTh, RGK after subtraction of the detector background. The Adamiec and Aitken (1998) conversion factors were applied to calculate the dose rates. Estimates of the cosmic-ray dose rate were determined using Prescott and Stephan (1982). We assumed an average water content of $10 \pm 5 \%$. The obtained dose rates are given in Table 2.

To obtain the values of the equivalent dose $\left(D_{\mathrm{e}}\right)$, we applied a single-aliquot regenerative (SAR) dose procedure (Murray and Wintle 2000). The pre-heating used was $260^{\circ} \mathrm{C}$ for $10 \mathrm{~s}$ for the OSL measurements, and a $220{ }^{\circ} \mathrm{C}$ cutheat for the sensitivity measurements. The measurements were performed using a Daybreak 2200 TL/OSL Bortolot 2000 reader, fitted with a calibrated beta-radiation source. The reader used blue diodes $(470 \pm 4 \mathrm{~nm})$ that delivered 


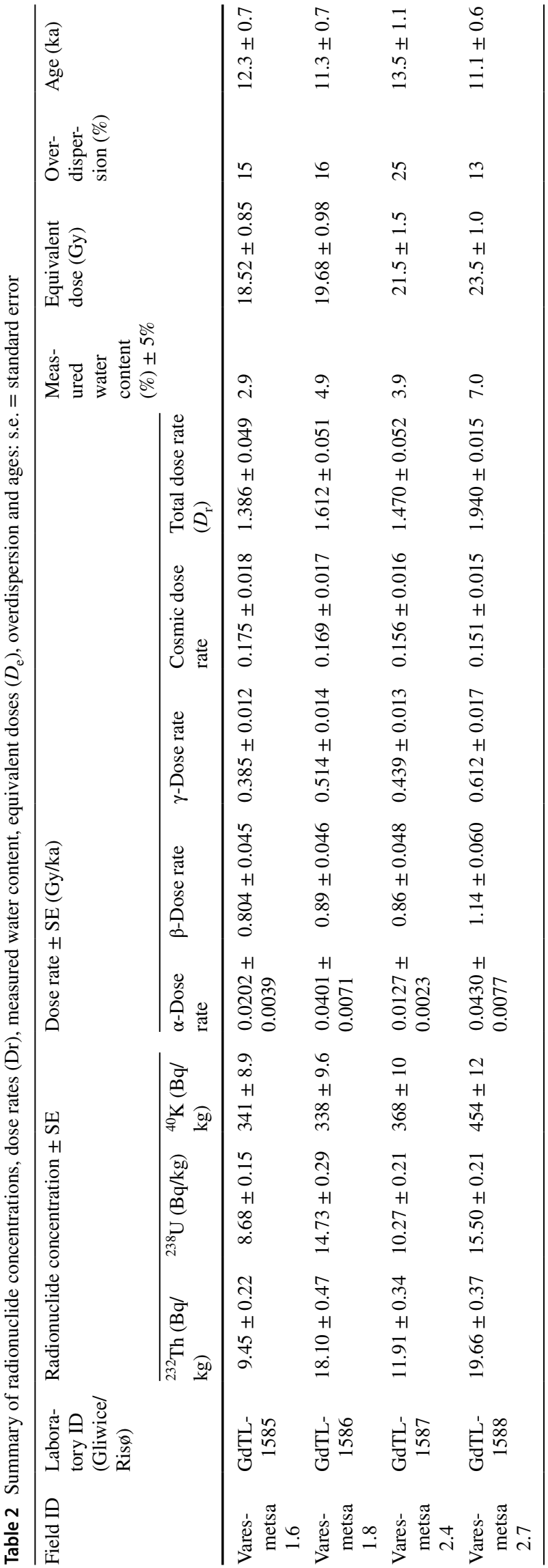

stimulating light of ca. $60 \mathrm{~mW} / \mathrm{cm}^{2}$ intensity to the sample and a $6 \mathrm{~mm}$ Hoya U-340 filter was used for OSL detection. Initial test measurements were carried out on three aliquots to obtain starting $D_{\mathrm{e}}$ estimates. For the actual measurements, three regenerative dose points were selected that bracketed the expected $D_{\mathrm{e}}$. In the SAR protocol, a zero-dose point and a repeat point were included. The data were fitted using a single saturating exponential, and the natural $D_{\mathrm{e}}$ was obtained by interpolation of the natural signal.

To calculate the final $D_{\mathrm{e}}$ s, the Central Age Model (CAM; Galbraith et al. 1999) was used for 16 (Sample GdTL-1585) and 15 (the rest of the samples) aliquots. The overdispersion is given in Table 2 .

\section{Results}

\section{Dune architecture}

Based on their reflection patterns, all three sediment sequences could be distinguished from their GPR profiles (Fig. 3). The Glaciolacustrine sequence is characterised by sets of parallel reflectors, indicating well-preserved layer thickness, representing a calm water regime (deeper waters). The reflectors undulates slightly where the layering likely followed the previous lakebed topography. The Aeolian 1 sequence also shows generally subhorizontal layering, but the reflectors had a wavy texture. Apparently, the Aeolian 1 pattern continues beyond the ridge, as a near-surface layer. This might suggest that a subsoil layer was reworked by wind. The Aeolian 2 sequence has a reflection pattern that is typical of dunes (Ludwig et al. 2017), with relatively weak reflectors being tilted in a downwind (eastward) direction. The transition from Aeolian 1 to Aeolian 2 is gradual in the top part of the dune, while the flat reflectors of Aeolian 1 continue as tilted the reflectors of Aeolian 2 on the eastern slope.

\section{Grain size}

The Glaciolacustrine sequence at Varesmetsa consist of coarse silts, very fine to fine sands, with a mean grain size of between 5.1 and 2.8 phi. The sediments are poorly to moderately well sorted, with generally positive value of skewness.

The Aeolian 1 sequence is represented by entirely finegrained, moderately- or poorly-sorted sand. The mean grain size varies between 2.2 and 2.9 phi, and the standard deviation ranged from 0.6 to 1.1 phi. The skewness values are between -0.1 and 0.1 .

The Aeolian 2 sequence consists of fine-, occasionally moderately-, grained sand (mean 1.9-2.9 phi), with a standard deviation of between 0.5 and 1.0 phi and a skewness between -0.2 and 0.2 . 
Fig. 3 GPR cross section of the Varesmetsa dune and its interpretation (inset)

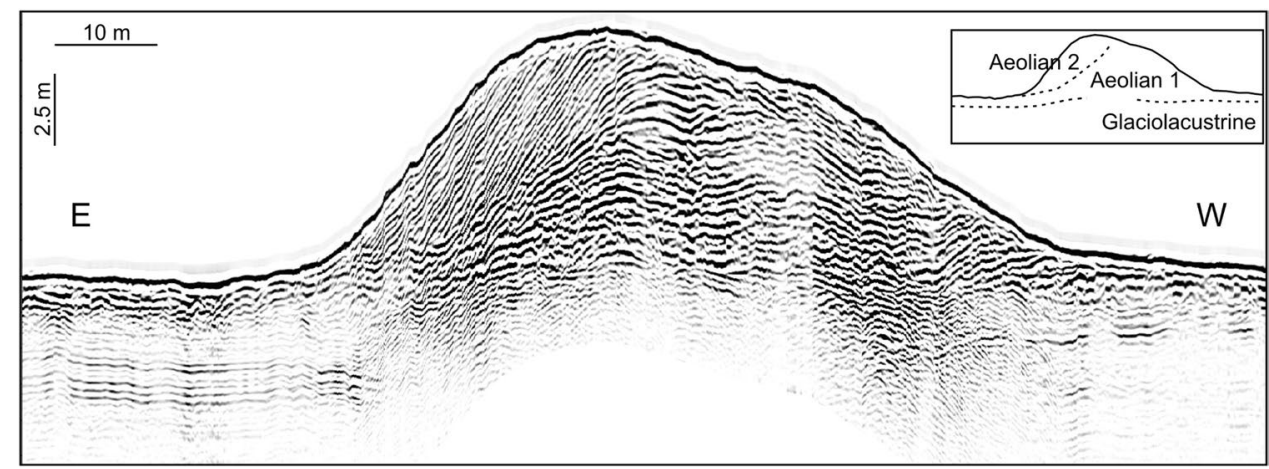

Iisaku 1 (Fig. 1) consists entirely of fine sand (mean 2.2-2.7 phi), with a standard deviation between 0.5 and $0.7 \mathrm{phi}$, and skewness values between -0.1 and 0.2 . At Iisaku 2, the sediments are represented by fine- and mediumgrained sand (mean 1.9-2.7 phi), which is moderately sorted $(\sigma=0.5-0.9 \mathrm{phi})$, with skewness values from -0.2 to 0.1 .

The cumulative curves of all the investigated sediments appear visually similar, especially among the Aeolian 1 of Varesmetsa and the Iisaku sites (Fig. 4a). The curves representing the grain-size distributions in the Glaciolacustrine and Aeolian 2 sequences are more diverse, which is due to poorer sediment sorting. A similar trend is observed from the standard deviation-mean biplot, where the Glaciolacustrine samples are slightly shifted towards poorer sorting.

\section{Character of quartz grains}

Quartz grains with matte surfaces are significant constituents of all the investigated samples and fractions (Fig. 5a). Partially-rounded matte grains make up as much as 41-64\%, $43-68 \%$ and $49-67 \%$ in the $0.5-0.8 \mathrm{~mm}$ fraction of the Glaciolacustrine, Aeolian 1 and Aeolian 2 sequences, respectively. The content of well-rounded grains with matte surfaces is as high as 33\% (e.g. in the Glaciolacustrine sequence), whilst being notably less in the $0.8-1.0 \mathrm{~mm}$ fraction of the investigated sediments. At the same time, the $0.8-1.0 \mathrm{~mm}$ fraction contains up to $72 \%$ of the partiallyrounded matte grains.

The content of intensively-precipitated grains varies between 11 and 32\% (in the Aeolian 1 and Glaciolacustrine sequences, respectively), and does not change significantly in the $0.8-1.0 \mathrm{~mm}$ fraction (between 10 and 38\%). Broken and partially-rounded grains with shiny surfaces are virtually absent from the investigated samples.

\section{Mineral composition}

Among the light minerals in the Varesmetsa sediments, quartz is the most common, with its content varying between 74 and $91 \%$ in the $0.5-0.8 \mathrm{~mm}$ fraction (Fig. 5a). Apparently, the quartz content slightly diminishes to $56-90 \%$ in the $0.8-1.0 \mathrm{~mm}$ fraction. A few mica-rich horizons $(85 \%$ and $37 \%$ in the $0.5-0.8 \mathrm{~mm}$ fraction) occur in Profiles 3 and 4 of the Glaciolacustrine and Aeolian 1 sequences, respectively. The platy mineral content in the $0.8-1.0 \mathrm{~mm}$ fraction is low, occasionally being $11-18 \%$ (Profile 3 ). The share of feldspar and crystalline rock particles varies from 5-15 to $1-11 \%$, respectively $(0.5-0.8 \mathrm{~mm}$ fraction), and is only slightly higher in the $0.8-1.0 \mathrm{~mm}$ fraction.

\section{Luminescence ages}

The present-day water content in the sampled aeolian sediments varies between $2.9 \pm 5$ and $7.0 \pm 5 \%$ (Table 2). The total dose rates are between 1.4 and $1.9 \mathrm{~Gy} / \mathrm{ka}$. Considering similar hydrogeological conditions for all the Varesmetsa and Iisaku samples, a lifetime average burial water content of $10 \pm 4 \%$ is used. This is similar to the value reported previously from the nearby Iisaku dunes (Kalińska-Nartiša et al. 2015b). The total dose rates are between 1.4 and $1.9 \mathrm{~Gy} /$ ka. The determined $D_{\mathrm{e}}$ values range from 18.6 to $23.5 \mathrm{~Gy}$, with a corresponding age range of between 11.1 and $13.5 \mathrm{ka}$. The $D_{\mathrm{e}}$ distributions are presented in Supplementary Figure $\mathrm{S} 1$. Nevertheless, there is a slight apparent inversion of the ages obtained from both profiles (Fig. 5b). The youngest age of $11.1 \pm 0.6 \mathrm{ka}$ occurs in the lowermost part of Profile 4 and is vertically inconsistent with a $30-\mathrm{cm}$ higher age of $13.5 \pm 1.1 \mathrm{ka}$ in the same profile. These ages correspond to within $2 \sigma$ of each other, while the two ages from Profile 5, showing a similar inversion, correspond within $1 \sigma$.

\section{Discussion}

Through macro- and micro-scale sediment studies and a chronological analysis, we have improved our understanding of the past processes involved in the glaciolacustrine deposits and their later aeolian mobilisation. The proxies provided here allow a better understanding of the depositional 


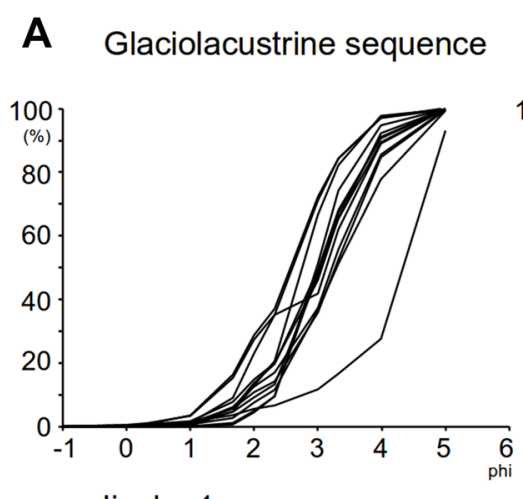

Aeolian 1 sequence

Aeolian 2 sequence

lisaku 1
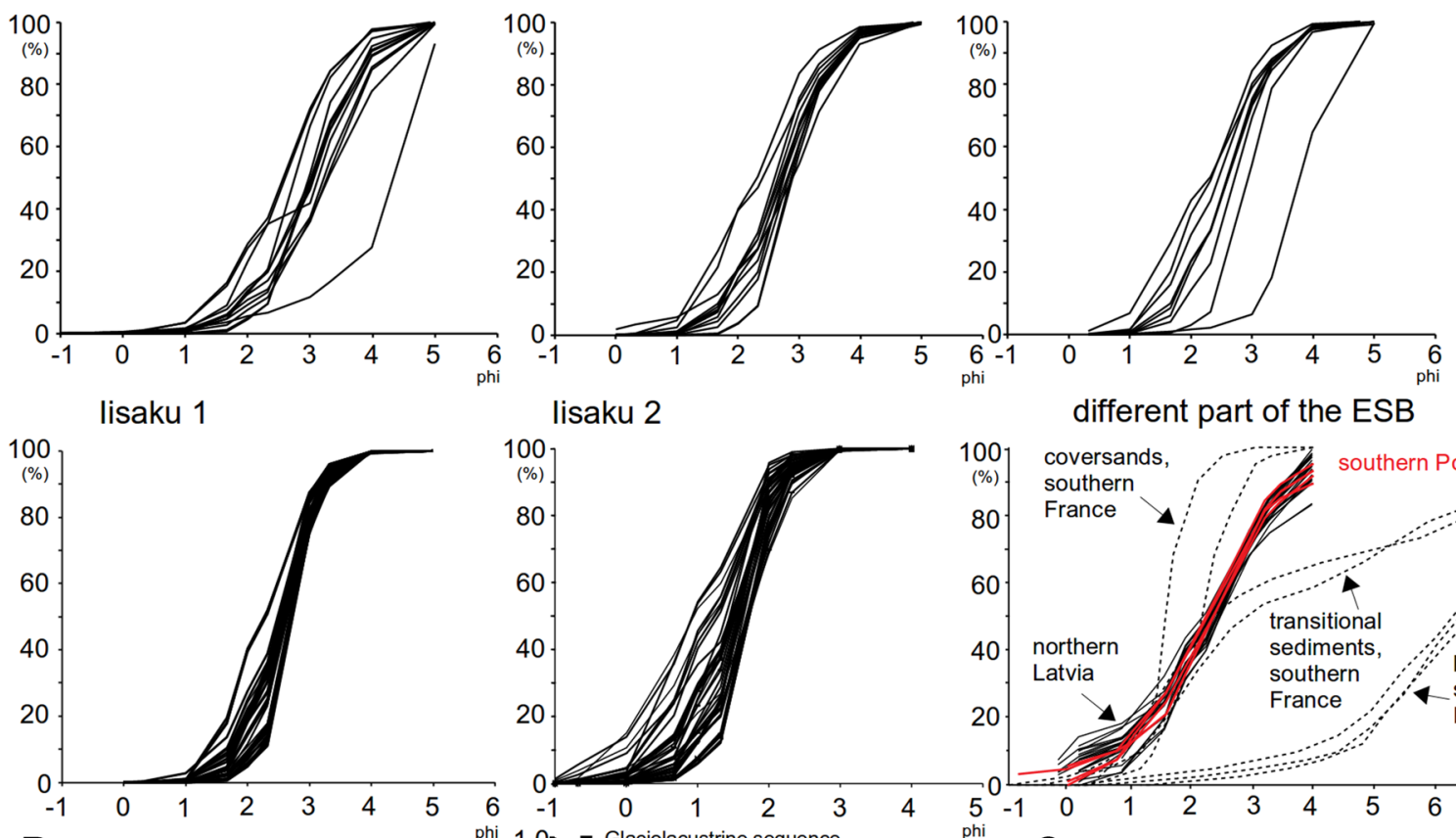

lisaku 2

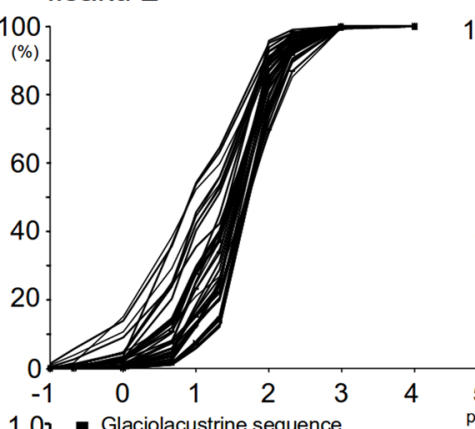

different part of the ESB

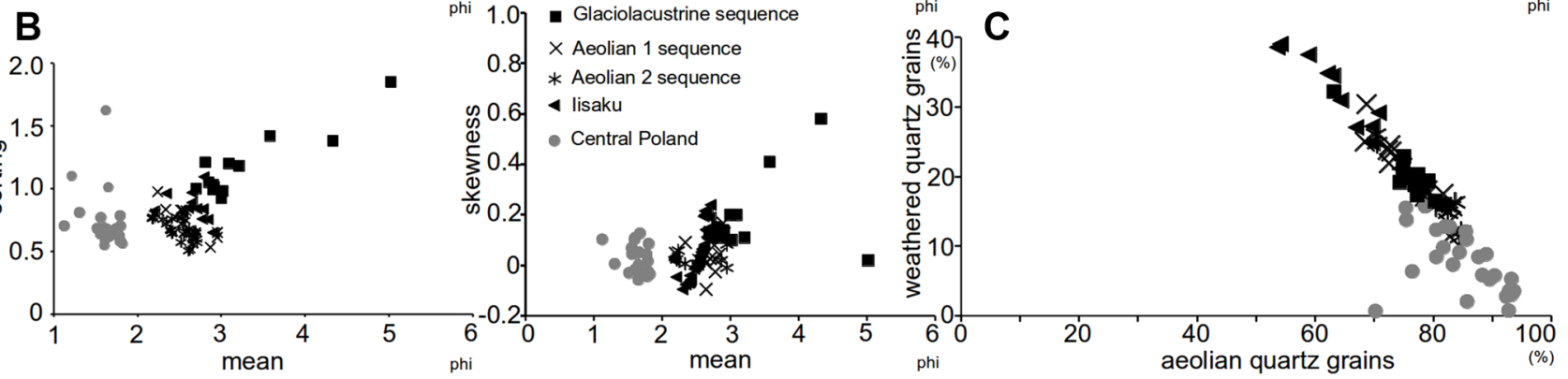

Fig. 4 Selected results of micro-scale sediment study along within the data from various parts of the ESB: a grain-size cumulative curves [data from southern France: Bertran et al. (2011)]; data from southern Poland and Latvia: unpublished data; Kalińska-Nartiša); b mean-sorting-skewness bi-plots (data from Central Poland: Kalińska 2012); c aeolian/weathered quartz grains bi-plot (data from Central Poland: Kalińska 2012)

this might be a change in sediment source. However, there is no sedimentological evidence to support this, since both the sedimentary structures and textural sediment features did not differ significantly. As far as the ages in the two profiles from Varesmetsa go, they corresponded within $1-2 \sigma$, and are considered to be identical.

\section{Past sedimentary processes at Varesmetsa}

Sedimentary structures, supported by the GPR images, are the basis for distinguishing among the lithological units at Varesmetsa. Applying this proxy, the subhorizontal, horizontal and wavy stratification of the fines and sand representing the Glaciolacustrine sequence are interpreted as being due to near-standing/low-energy water conditions (cf. Salamon and Zieliński 2010), modified by occasional flows 


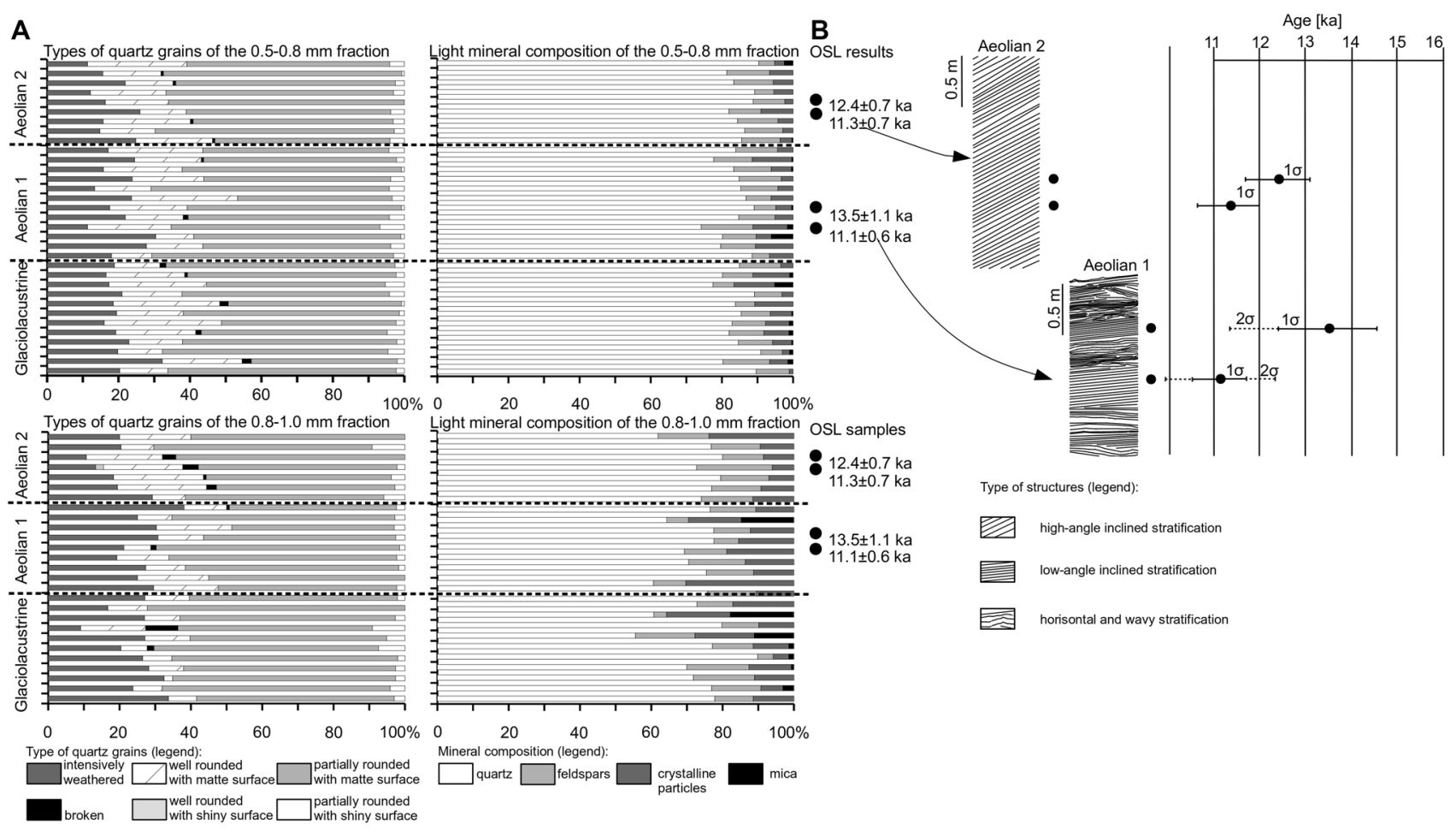

Fig. 5 a Types of quartz grains and light mineral composition of $0.5-0.8$ and $0.8-1.0 \mathrm{~mm}$ fractions; b luminescence age inversion as seen in two sediment profiles

in a shallow glacial lake (cf. Ojala et al. 2000). Wet conditions support well-preserved mica horizons. The platy nature of mica requires slow-changing depositional conditions to allow it to settle (Pisarska-Jamroży et al. 2015), requiring 30-50\% more time than spherical grains for its deposition (Komar 1989). A water-table-controlled environment, as represented by the Glaciolacustrine sequence and occasionally by the Aeolian 1 sequence (see below), provides the ideal conditions for mica-like minerals settling from suspension in standing water (Marcinkowski and MycielskaDowgiałło 2013; Vandenberghe et al. 2013). The continuous nature of the sand layers in the Aeolian 1 sequence (Fig. 3), with occasional mica-rich layers (Fig. 5), indicates deposition in a sediment-rich environment, such as the wind erosion of a former lakebed (represented by the Glaciolacustrine sequence). The Aeolian 2 sequence is determined to be a continuation of the Aeolian 1 sequence, with a few significant differences, such as a lack of sedimentation on the stoss (windward) slope and an almost complete absence of micas. Most likely, the Aeolian 2 sequence was formed by redeposition of the stoss slope sediments on the lee slope. This would indicate formation under sediment-deprived conditions, most likely the development of vegetation over the former lakebed depriving the dune of fresh incoming sediments, especially of easily-removable mica (cf. Anderson et al. 2017).
Certain results obtained from the micro-scale study argued for the Glaciolacustrine and Aeolian environments to be closely related, meaning that the aeolian action was limited. Brief aeolian reworking can be seen, for example, through grain-size analysis and the type of quartz grains. The granulometric properties of the investigated sediments appears to be largely similar, not only among the sequences, but also in a regional comparison with the dune sediments of the Iisaku sites, and with other parts of the ESB, such as the dunes in northern Latvia and the coversands in southern Poland and France (Fig. 4a, b). Only sediment sorting and skewness can help to differentiate among these regional Glaciolacustrine and Aeolian sequences (Fig. 4b).

Usually, a glaciolacustrine sedimentary environment exhibits either a mixture of quartz grain shapes (Narayana et al. 2010) or angularity, abrasion and a high frequency of fracturing (Mahaney et al. 2004, 2014), but such grains are almost absent from this study's Glaciolacustrine sequence. Instead, grains with signs of aeolian action on their convex parts (partially rounded, matte) dominate. Aeolian grains from the Glaciolacustrine sequence are expected because a relatively large input of aeolian-type quartz grains had already been observed in: (1) the lowermost portion of the glaciolacustrine deposits of the nearby Iisaku sites (Kalińska-Nartiša et al. 2015a); (2) the glaciofluvial material of the adjacent Iisaku-Illuka esker, which served as 
a potential source (Kalińska-Nartiša, unpublished data); and, finally, (3) the pre-Quaternary formations in Estonia that possess aeolian grains (Kleesment 2009). In addition, a prevalence of aeolian quartz grains has previously been noted in sediments from various palaeoenvironments, such as fluvial, fluvioperiglacial and aeolian, in Poland (Woronko et al. 2015; Zieliński et al. 2015) and in Western Europe (Vandenberghe et al. 2013; Sitzia et al. 2015). Following all these pieces of evidence, the material of aeolian origin is believed to be allochtonic in the Varesmetsa Glaciolacustrine sequence, delivered to the glacial lake as the result of aeolian activity that spanned either a short time or short distance (cf. Woronko et al. 2015). The Glaciolacustrine sequence, therefore, represents cold and dry climatic conditions in the foreland of the Pandivere-Neva marginal zone, where the glacial lake existed.

Neither the Aeolian 1 or Aeolian 2 sequences differ significantly from the Glaciolacustrine sequence, in terms of quartz grain characteristics, with grains of different shapes possessing matte surface dominating. However, the numbers of such characteristic grains are much lower than in, for example, the central part of the ESB (Woronko et al. 2015), where aeolian activity was more intense (Zieliński et al. 2016a). More well-rounded grains occur in the sediments of the Aeolian 1 sequence in the $0.8-1.0 \mathrm{~mm}$ fraction, and in Aeolian 2 sequence compared with the Aeolian 1 sequence. This could be explained by the fact that (1) the sediments of the Aeolian 1 sequence were the source of the Aeolian 2 sequence sediments, and/or (2) a generally stronger aeolian abrasion is observed in this fraction size (Dzierwa and Mycielska-Dowgiałło 2003; Kotilainen 2004). Following the above-mentioned similarities, and concerning the intensity of the aeolian processes, contrary to the central part of the ESB, these grains experienced only slight aeolian transformation, and so the source of the material was likely entirely a local aquaeoglacial deposit.

\section{Aeolian chronology at Varesmetsa and its context}

Our luminescence ages ranged from $13.5 \pm 1.1$ to $11.1 \pm 0.6 \mathrm{ka}$ at Varesmetsa, which argues for continuous aeolian deposition (Fig. 5b). The oldest age obtained in this study slightly postdates the Pandivere Stadial, which lasted from 14,000 to 13,800 cal year BP, according to the latest study by Amon et al. (2016). The Varesmetsa site is located in the ice-free area between the Last Glacial Maximum and the local Baltic Ice Lake coastline at this time (Lasberg and Kalm 2013), on an island, which existed there during the Baltic Ice Lake $\mathrm{A}_{2}$ stage at ca. 13,300 cal year BP (Vassiljev and Saarse 2013). Modelling results have shown that the $\mathrm{A}_{2}$ water-level was lowered by ca. $15 \mathrm{~m}$ at this time, being as high as ca. $48-50 \mathrm{~m}$ above the present-day sea level (Fig. 6; Rosentau et al. 2004; Vassiljev and Saarse 2013).
Considering possible past water-level fluctuations, which in this flat, sandy terrain likely induced high-amplitude shoreline displacement, the conditions were favourable for periodic aeolian action, leading to dune formation with a foot altitude at ca. 45-50 m (Fig. 6). The low altitudes of these coastal dunes are also reflected in the dune morphology, as all individual dunes in the area are parabolic, with horns standing against the prevailing wind, indicating the presence of a moist bed. Combining these facts with the deglaciation scheme of Estonia, in which the ice sheet still covered part of NW Estonia, katabatic winds would have been induced towards the periglacial area, resulting in aeolian deposition onto dry land north of the regressive Glacial Lake Peipsi. Following our OSL ages, the aeolian deposition started at ca. 13.5-13.3 ka in NE Estonia (and up to ca. 14.5 ka BP, if considering the error bars; see Fig. 6). Following lakelevel reconstruction, the ca. 13.5-ka water-level still seems to be higher than the dominating dune foot altitude (Fig. 6); however, the presented reconstruction is only tentative, and likely water-level fluctuations should be considered. Aeolian activity was favoured by (1) a winter mean temperature of ca. $-14{ }^{\circ} \mathrm{C}$ and a summer temperature of between ca. 10 and $13{ }^{\circ} \mathrm{C}$, according to pollen-based reconstructions (Veski et al. 2015); (2) a presumable lack of trees for the entire Late Glacial period in northern Estonia, and the occurrence of sparse pioneering vegetation, such as treeless tundra (Amon et al. 2014); and (3) a likely lower than modern annual precipitation, enhancing continental conditions compared to the present-day climate (cf. Feurdean et al. 2014).

A single luminescence age of $12.4 \pm 0.7 \mathrm{ka}$ at Varesmetsa is likely related to a considerable ground-water-level drop in the region, which took place between 13,300 and 12,200 cal year BP (Vassiljev and Saarse 2013), thus giving a time window for dune deposition (Fig. 6). Assuming also a general temperature and precipitation drop (Rasmussen et al. 2006; Feurdean et al. 2014; Veski et al. 2015), along with an occurrence of herb-dwarf-dominated shrubs in the region (Amon et al. 2012), loose material may easily have been mobilised by wind and deposited on the leeward slopes of the migrating dunes, as recorded at Varesmetsa (Fig. 6). Aeolian activity at Varesmetsa terminated between $11.3 \pm 0.7$ and $11.1 \pm 0.6 \mathrm{ka}$, which represents a similar time frame to that at Iisaku (Kalińska-Nartiša et al. 2015a). Later aeolian activity was hampered because paludification started at ca. $10 \mathrm{ka}$ in the region (Fig. 6; Hiiemaa et al. 2014).

\section{Aeolian events in the eastern Baltic region and in Western Europe}

The OSL ages obtained in our study are largely consistent with those of previous studies in the region of the Baltic States. For example, the OSL age of ca. 13.5 ka from Varesmetsa corresponds well with similar aeolian deposition in 


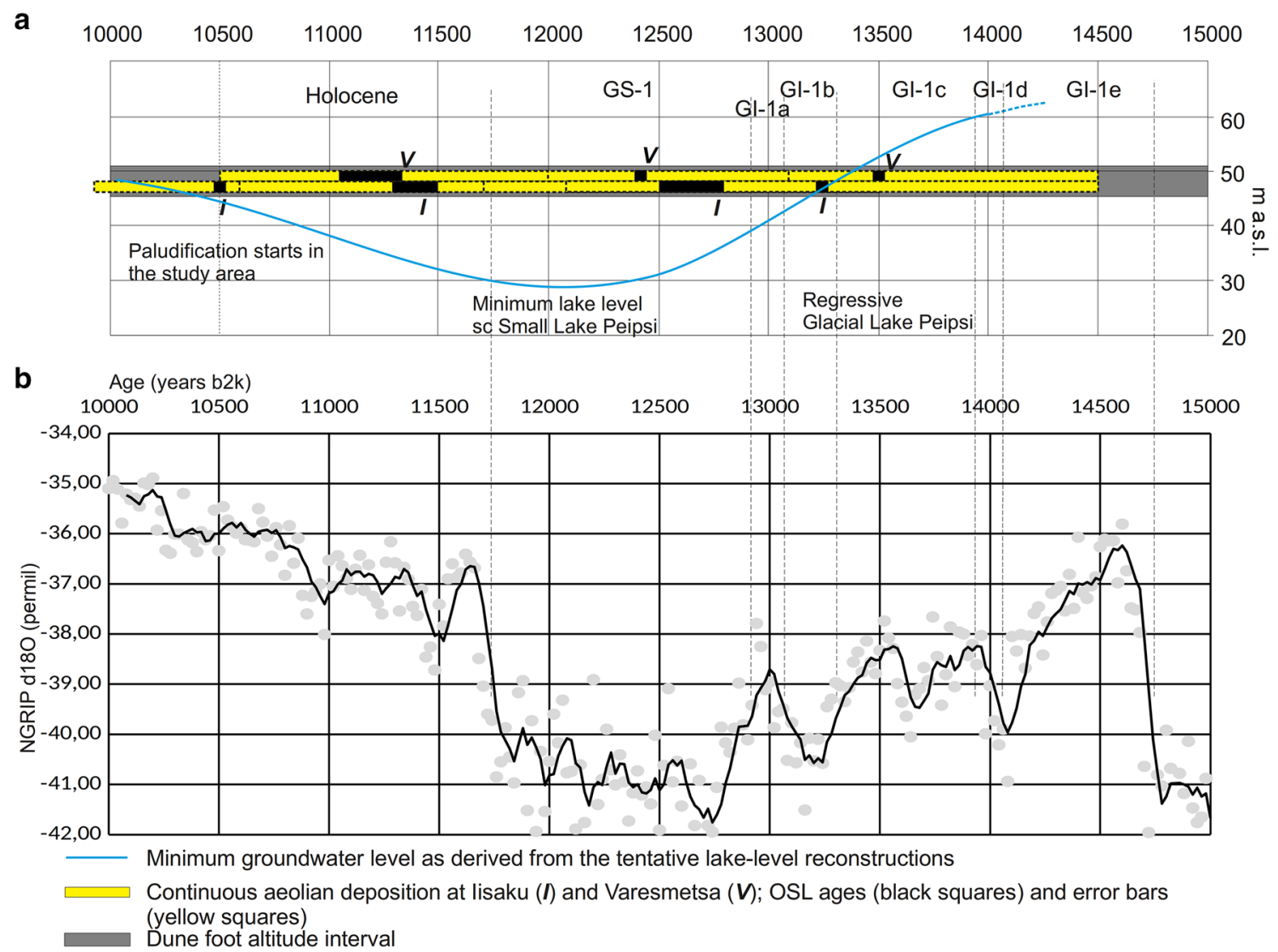

Fig. 6 a Tentative minimum groundwater-level in the study area as derived from the modelled water-level changes of Glacial Lake Peipsi (Rosentau et al. 2004; Vassiljev and Saarse 2013) with the indication

eastern Latvia and Lithuania (Table 2), and likely reflects the colder GI-1b episode in the North Greenland Ice Core Project (NGRIP) event stratigraphy (Fig. 6; Rasmussen et al. 2006). Accumulation of the so-called Younger Coversand II took place in Western Europe in a similar time frame (Vandenberghe et al. 2013). Sand mobilisation at ca. $12.4 \mathrm{ka}$, as recorded in this study, correlates well with dune migration in southern Estonia (Kalińska-Nartiša et al. 2016), which is further consistent with the cold GS-1 Greenland Event (Fig. 6; Steffensen et al. 2008). Previous studies, as well as this research, have demonstrated that the time span for aeolian sediment mobilisation seems to have been extended in this part of the ESB, contrary to in its western and central parts in the rest of Europe, where periods of aeolian mobility alternated with palaeosol development (Bertran et al. 2011; Tolksdorf et al. 2013; Vandenberghe et al. 2013; Küster et al. 2014; Beerten and Leterme 2015; Zieliński et al. 2015, 2016a, b; Hirsch et al. 2017). In the Baltic region, so far, no buried soils have been found among the aeolian sediments of the NE ESB, except for discontinuous, lens-like and diffuse darkish organic material in eastern Latvia (Kalińska-Nartiša et al. 2016; Kalińska 2019). At Iisaku, four phases of aeolian of dune foot altitude, periods of aeolian activity derived from luminescence ages. b NGRIP d18O (\%o) data (Rasmussen et al. 2006)

activity have been documented; however, the luminescence ages represent more of a continuous time span between ca. 13.3 and $10.5 \mathrm{ka}$ (Kalinska-Nartiša et al. 2015a, b), rather than well-expressed events. A record of such stability, apparent from palaeosols, for instance, is practically absent. This indicates harsh climatic conditions, favouring sparse pioneering vegetation that was incapable of seriously hampering aeolian activity. Because the study area was located on an island in the regressive Glacial Lake Peipsi, this might also have slowed down the formation of a dense vegetation cover, compared to the neighbouring upland area. On the other hand, the palaeosol record may have been erased by constantly changing water levels in the glacial lake, where, due to wave action, the development of pioneering vegetation and soil was hampered.

It has been assumed that aeolian activity reflects the progress of a deglaciation (Zeeberg 1998). Following this assumption, aeolian activity would have started earlier in Lithuania than in Estonia. Unfortunately, our chronological data, together with earlier age determinations of aeolian sands from the Baltic States, do not support this assumption. Thus, the earliest aeolian activity in central Lithuania (ca. 
$16 \mathrm{ka}$ ) and southern Latvia (ca. $15 \mathrm{ka}$ ) predate, by ca. 2 and $1 \mathrm{ka}$, respectively, the earliest wind activity in southern Lithuania (ca. 14 ka; Table 2; Kalińska-Nartiša et al. 2015b). The following pulse of wind events at around 13-13.5 ka was synchronous in northern Lithuania, eastern Latvia and northern Estonia. Between ca. 12 and $11 \mathrm{ka}$, both the northern and southern Estonian dunes were formed, together with the dunes in southern Lithuania (Molodkov and Bitinas 2006). The remaining ages show aeolian deposition at around $9 \mathrm{ka}$ in eastern Latvia, which continued later into the Holocene, as reflected in the Lithuanian localities (Molodkov and Bitinas 2006). In summary, we did not see the expected chronological order, from south to north, as proposed by Zeeberg (1998), which might be due to either local conditions, such as suitable source sediments, the evolution of meltwater basins, the occurrence of pioneering vegetation or too few age determinations.

\section{Conclusions}

In the foreland of the Late Weichselian Pandivere-Neva marginal zone in NE Estonia, wind action resulted in significant aeolian landforms, with clear aeolian sediment architecture. However, micro-scale sediment properties, such as grainsize, the shape and character of quartz grain surfaces, and overall mineral compositions of the Varesmetsa dune, argue for short-distance sediment transport during a brief aeolian event, where sediment recycling is practically undetectable.

The luminescence ages showed that dune development took place between $13.5 \pm 1.1$ and $11.1 \pm 0.6 \mathrm{ka}$. However, it was largely controlled by changes in the water level of the Glacial Lake Peipsi. Aeolian deposition started at 13.5-13.3 ka in NE Estonia, when the lake was at a stand of 48-50 $\mathrm{m}$ a.s.l., and dry land existed directly in front of the glacier. This deposition took place during the colder GI-1b episode and correlates with the Younger Coversand II succession known from Western Europe.

Later, deposition was possible due to a considerable water-level drop and a decrease in precipitation during the GS-1 cooling. Drier conditions made sediment easier to mobilise, which resulted in deposition on the leeward slopes of the migrating dunes. Aeolian activity continued up to $11.3-11.1 \mathrm{ka}$, and even to $10.5 \mathrm{ka}$ at the neighbouring Iisaku site, and ended when paludification started in the region.

Acknowledgements Dr. Tony Reimann (Wageningen University) and unknown reviewer are thanked for reviews that improved this manuscript. This research was supported by the Postdoctoral Research Grant ERMOS (FP7 Marie Curie Co-fund the 'People programme'), 'Age and climatic signature of coversands deposits distributed on glaciolacustrine basins along the Scandinavian Ice Sheet margin southeast of the Baltic Sea'.
Open Access This article is distributed under the terms of the Creative Commons Attribution 4.0 International License (http://creativeco mmons.org/licenses/by/4.0/), which permits unrestricted use, distribution, and reproduction in any medium, provided you give appropriate credit to the original author(s) and the source, provide a link to the Creative Commons license, and indicate if changes were made.

\section{References}

Adamiec A, Aitken M (1998) Dose-rate conversion factors: update. Ancient TL 16:37-50

Alexanderson H, Bernhardson M (2016) OSL dating and luminescence characteristics of aeolian deposits and their source material in Dalarna, central Sweden. Boreas 45(4):876-893. https:// doi.org/10.1111/bor.12197

Alexanderson H, Murray AS (2007) Was southern Sweden ice free at 19-25 ka, or were the post LGM glacifluvial sediments incompletely bleached? Quat Geochronol 2:229-236. https://doi. org/10.1016/j.quageo.2006.05.007

Amon L, Veski S, Heinsalu A, Saarse L (2012) Timing of Lateglacial vegetation dynamics and respective palaeoenvironmental conditions in southern Estonia: evidence from the sediment record of Lake Nakri. J Quat Sci 27:169-180. https://doi.org/10.1002/ jqs. 1530

Amon L, Veski S, Vassiljev J (2014) Tree taxa immigration to the eastern Baltic region, southeastern sector of Scandinavian glaciation during the Late-glacial period (14,500-11,700 cal. BP). Veg Hist Archeobot 23(3):207-216. https://doi.org/10.1007/s0033 4-014-0442-6

Amon L, Saarse L, Heinsalu A, Veski S (2016) Timing of the deglaciation and the late-glacial vegetation development on the Pandivere Upland, North Estonia. Bull Geol Soc Finl 88:69-83

Anderson CJ, Struble A, Whitmore JH (2017) Abrasion resistance of muscovite in aeolian and subaqueous transport experiments. Aeolian Res 24:33-37. https://doi.org/10.1016/j.aeoli a.2016.11.003

Bateman MD, Murton JB (2006) The chronostratigraphy of Late Pleistocene glacial and periglacial aeolian activity in the Tuktoyaktuk Coastlands, NWT, Canada. Quat Sci Rev 25:25522568. https://doi.org/10.1016/j.quascirev.2005.07.023

Beerten K, Leterme B (2015) Palaeohydrological reconstruction (1500-2000AD) of a drift sand landscape using pedogeomorphological and historical data (Campine area, NE Belgium). CATENA 135:208-218. https://doi.org/10.1016/j.caten a.2015.07.022

Beerten K, Vandersmissen N, Deforce K, Vandenberghe N (2014) Late Quaternary (15 ka to present) development of a sandy landscape in the Mol area, Campine region, north-east Belgium. J Quat Sci 29:433-444. https://doi.org/10.1002/jqs.2713

Bertran P, Bateman MD, Hernandez M, Mercier N, Millet D, Sitzia L, Tastet J-P (2011) Inland aeolian deposits of south-west France: facies, stratigraphy and chronology. J Quat Sci 26:374388. https://doi.org/10.1002/jqs.1461

Bertran P, Sitzia L, Banks WE, Bateman M, Demars P-Y, Hernandez M, Lenoir M, Mercier N, Prodeo F (2013) The Landes de Gascogne (southwest France): periglacial desert and cultural frontier during the Palaeolithic. J Archaeol Sci 40:2274-2285. https://doi.org/10.1016/j.jas.2013.01.012

Bertran P, Liard M, Sitzia L, Tissoux H (2016) A map of Pleistocene aeolian deposits in Western Europe, with special emphasis on France. J Quat Sci 31(8):844-856. https://doi.org/10.1002/ jqs.2909 
Blott SJ, Pye K (2001) Gradistat: a grain size distribution and statistic package for the analysis of unconsolidated sediments. Earth Surf Process Landf 26:1237-1248. https://doi.org/10.1002/esp.261

Bortolot VJ (2000) A new modular high capacity OSL reader system. Radiat Meas 32(5-6):751-757. https://doi.org/10.1016/S1350 $-4487(00) 00038-\mathrm{X}$

Cailleux A (1942) Les actiones éoliennes périglaciaires en Europe. Mém Soc Géol Fr 41:1-176

Clarke DW, Boyle JF, Chiverrell RC, Lario J, Plater AJ (2014) A sediment record of barrier estuary behaviour at the mesoscale: interpreting high-resolution particle size analysis. Geomorphology 221:51-68. https://doi.org/10.1016/j.geomorph.2014.05.029

Derese C, Vandenberghe D, Paulissen E, Van den Haute P (2009) Revisiting a type locality for Late Glacial aeolian sand deposition in NW Europe: optical dating of the dune complex at Opgrimbie (NE Belgium). Geomorphology 109:27-35. https://doi. org/10.1016/j.geomorph.2008.08.022

Drenova AN, Timireva SN, Chikolini NI (1997) Late glacial dunebuilding in the Russian plain. Quat Int 41(42):59-66. https://doi. org/10.1016/S1040-6182(96)00037-7

Dzierwa K, Mycielska-Dowgiałło E (2003) Reconstruction of the dynamics of aeolian processes and of their duration on the basis of selected textural feature of the deposits within the dune at Cięciwa (Eastern Poland). Przegląd Geol 51:163-167 (in Polish with English abstract)

Feurdean A, Perşoiu A, Tanţău I, Stevens T, Magyari EK, Onac BP, Marković S, Andrič M, Connor S, Fărcaş S, Gałka M, Gaudeny T, Hoek W, Kolaczek P, Kuneš P, Lamentowicz M, Marinova E, Michczyńska DJ, Perşoiu I, Płóciennik M, Słowiński M, Stancikaite M, Sumegi P, Svensson A, Tămaş T, Timar A, Tonkov S, Toth M, Veski S, Willis KJ, Zernitskaya V (2014) Climate variability and associated vegetation response throughout Central and Eastern Europe (CEE) between 60 and 8ka. Quat Sci Rev 106:206-224. https://doi.org/10.1016/j.quascirev.2014.06.003

Folk RL, Ward WC (1957) Brazos River bar: a study in the significance of grain size parameters. J Sediment Petrol 27:3-26

Galbraith RF, Roberts RG, Laslett GM, Yoshida H, Olley YM (1999) Optical dating of single and multiple grains of quartz from Jinmium rock shelter, Northern Australia: part I, Experimental design and statistical models. Archaeometry 41:339-364. https ://doi.org/10.1111/j.1475-4754.1999.tb00987.x

Guobytė R, Satkūnas J (2011) Chapter 19-Pleistocene glaciations in Lithuania. Dev Quat Sci 15:231-246. https://doi.org/10.1016/ B978-0-444-53447-7.00019-2

Hang T (2001) Proglacial sedimentary environment, varve chronology and Late Weichselian development of the Lake Peipsi, eastern Estonia. Quaternaria. Ser. A, 11, Stockholm

Hang T (2003) A local clay-varve chronology and proglacial sedimentary environment in glacial Lake Peipsi, eastern Estonia. Boreas 32:416-426. https://doi.org/10.1080/03009480310003658

Hang T, Ojala A, Kohv M, Tuvikene T (2011) Varve chronology and proglacial sedimentary environment in Pärnu area, western Estonia. In: Johansson P, Lunkka JP, Sarala P (eds) Late pleistocene glacigenic deposits from the Central part of the Scandinavian Ice Sheet to Younger Dryas End Moraine Zone. Geological Survey of Finland, Rovaniemi, pp 94-95

Hiiemaa H, Mustasaar M, Kohv M, Hang T, Jõeleht A, Lasberg K, Kalm V (2014) Geological settings of the protected Selisoo mire (northeastern Estonia) threatened by oil shale mining. Est J Earth Sci 63(2):97-107. https://doi.org/10.3176/earth.2014.09

Hirsch F, Spröte R, Fischer T, Forman SL, Raab T, Bens O, Schneider A, Hüttl RF (2017) Late Quaternary aeolian dynamics, pedostratigraphy and soil formation in the North European Lowlands - new findings from the Baruther ice-marginal valley. Die Erde J Geogr Soc Berlin 148:58-73. https://doi.org/10.12854/ erde-148-30
Houmark-Nielsen M (2008) Testing OSL failures against a regional Weichselian glaciation chronology from southern Scandinavia. Boreas 37:660-677. https://doi.org/10.111 1/j.1502-3885.2008.00053.x

Kajak K (1963) Peipsi nõo geoloogiast ja geomorfoloogiast. Eesti Geograafia Seltsi Aastaraam 1963:20-33

Kalińska E (2012) Geological setting and sedimentary characteristics of the coversands distributed in the western part of the Blonie glaciolacustrine basin (Central Poland)—preliminary results. Bull Geol Soc Finl 84:33-44

Kalińska E (2019) Understanding a continuous inland aeolian deposition: a closer look into a chronological and sedimentary record of the north-eastern European Sand Belt. Bull Geogr Phys Geogr Ser 16:31-41. https://doi.org/10.2478/bgeol-2019-0003

Kalińska-Nartiša E, Gałka M (2018) Sand in Early Holocene lake sediments-a microscopic study from Lake Jaczno, northeastern Poland. Est J Earth Sci 67(2):122-132. https://doi.org/10.3176/ earth.2018.09

Kalińska-Nartiša E, Nartišs M, Thiel C, Buylaert JP, Murray AS (2015a) Late-glacial to Holocene aeolian deposition in northeastern Europe-the timing of sedimentation at the Iisaku site (NE Estonia). Quat Int 357:70-81. https://doi.org/10.1016/j.quain t.2014.08.039

Kalińska-Nartiša E, Thiel C, Nartišs M, Buylaert JP, Murray AS (2015b) Age and sedimentary record of inland aeolian sediments in Lithuania, NE European Sand Belt. Quat Res 84:82-95. https ://doi.org/10.1016/j.yqres.2015.04.001

Kalińska-Nartiša E, Thiel C, Nartišs M, Buylaert JP, Murray AS (2016) The north-eastern aeolian "European Sand Belt" as potential record of environmental changes: a case study from Eastern Latvia and Southern Estonia. Aeolian Res 22:59-72. https://doi. org/10.1016/j.aeolia.2016.06.002

Kalińska-Nartiša E, Stivrins N, Grudzinska I (2017a) Quartz grains reveal sedimentary palaeoenvironment and past storm events: a case study from eastern Baltic. Estu Coast Shelf Proc 200:359 370. https://doi.org/10.1016/j.ecss.2017.11.027

Kalińska-Nartiša E, Woronko B, Ning W (2017b) Microtextural inheritance on quartz sand grains from Pleistocene periglacial environments of the Mazovian Lowland, central Poland. Permafr Periglac Process 28:741-756. https://doi.org/10.1002/ppp.1943

Kalm V (2006) Pleistocene chronostratigraphy in Estonia, southeastern sector of the Scandinavian glaciation. Quat Sci Rev 25:960-975. https://doi.org/10.1016/j.quascirev.2005.08.005

Kalm V, Raukas A, Rattas M, Lasberg K (2011) Pleistocene Glaciations in Estonia. In: Ehlers J, Gibbard PL, Hughes PD (eds) Quaternary glaciations - extent and chronology, 1st edn. Elsevier Inc., Amsterdam, pp 95-104

Karukäpp R, Raukas A (1999) Deglaciation of the lake basin. In: Miidel A, Raukas A (eds) Lake Peipsi. Geology. Sulemees Publishers, Tallinn, pp 125-130

Kasse C, Vandenberghe D, De Corte F, Van Den Haute P (2007) Late Weichselian fluvio-aeolian sands and coversands of the type locality Grubbenvorst (southern Netherlands): sedimentary environments, climate record and age. J Quat Sci 22:695-708. https:// doi.org/10.1002/jqs.1087

Käyhkö JA, Worsley P, Pye K, Clarke ML (1999) A revised chronology for aeolian activity in subarctic Fennoscandia during the Holocene. Holocene 9:195-205. https://doi.org/10.1191/0959683996 68228352

Kleesment A (2009) Roundness and surface features of quartz grains in Middle Devonian deposits of the East Baltic and their palaeogeographical implications. Est J Earth Sci 58:71-84. https://doi. org/10.3176/earth.2009.1.07

Komar PD (1989) Physical processes of waves and currents and the formation of marine placers. CRC Crit Rev Aquat Sci 1:637-655 
Koster EA (1988) Ancient and modern cold-climate aeolian sand deposition: a review. J Quat Sci 3:69-83

Koster EA (2005) Recent advances in luminescence dating of Late Pleistocene (cold-climate) aeolian sand and loess deposits in western Europe. Permafr Periglac Process 16(1):131-143. https://doi. org/10.1002/ppp.512

Koster EA (2009) The "European Aeolian Sand Belt": geoconservation of drift sand landscapes. Geoheritage 1:93-110. https://doi. org/10.1007/s12371-009-0007-8

Kotilainen M (2004) Dune stratigraphy as an indicator of Holocene climatic change and human impact in Northern Lapland, Finland. Ann Acad Sci Fenn Geol 166:1-158

Küster M, Fülling A, Kaiser K, Ulrich J (2014) Aeolian sands and buried soils in the Mecklenburg Lake District, NE Germany: holocene land-use history and pedo-geomorphic response. Geomorphology 211:64-76. https://doi.org/10.1016/j.geomo rph.2013.12.030

Lasberg K, Kalm V (2013) Chronology of Late Weichselian glaciation in the western part of the East European Plain. Boreas 42:995-1007. https://doi.org/10.1111/bor.12016

Lu H, Stevens T, Yi S, Sun X (2006) An erosional hiatus in Chinese loess sequences revealed by closely spaced optical dating. Chin Sci Bull 51:2253-2259. https://doi.org/10.1007/s1143 4-006-2097-x

Ludwig J, Lindhorst S, Betzler C, Bierstedt SE, Borówka RK (2017) Sedimentary rhythms in coastal dunes as a record of intraannual changes in wind climate (Łeba, Poland). Aeolian Res 27:67-77. https://doi.org/10.1016/j.aeolia.2017.06.003

Madsen AT, Murray AS (2009) Optically stimulated luminescence dating of young sediments: a review. Geomorphology 109:3-16. https://doi.org/10.1016/j.geomorph.2008.08.020

Mahaney WC, Dirszowsky RW, Milner MW, Menzier J, Stewart A, Kalm V, Bezada M (2004) Quartz microtextures and microstructures owing to deformation of glaciolacustrine sediments in the northern Venezuelan Andes. J Quat Sci 19:23-33. https://doi. org/10.1002/jqs. 818

Mahaney WC, Hancock RGV, Milan A, Pulleyblank C, Costa PJM, Milner MW (2014) Reconstruction of Wisconsinan-age ice dynamics and compositions of southern Ontario glacial diamictons, glaciofluvial/lacustrine, and deltaic sediment. Geomorphology 206:421-439. https://doi.org/10.1016/j.geomo rph.2013.10.014

Marcinkowski B, Mycielska-Dowgiałło E (2013) Heavy-mineral analysis in Polish investigations of quaternary deposits: a review. Geologos 19:5-23. https://doi.org/10.2478/logos $-2013-0002$

Mardla EE (1967) The geological map of USSR (quaternary deposits) 1:200,000, O-35-IV sheet. Moscow

Mejdahl V (1979) Thermoluminescence datings: beta attenuation in quartz grains. Archaeometry 21:61-73

Molodkov A, Bitinas A (2006) Sedimentary record and luminescence chronology of the Lateglacial and Holocene aeolian sediments in Lithuania. Boreas 35:244-254. https://doi.org/10.1080/03009 480600584915

Muhs DR (2004) Mineralogical maturity in dunefields of North America, Africa and Australia. Geomorphology 59:247-269. https:// doi.org/10.1016/j.geomorph.2003.07.020

Murray AS, Wintle AG (2000) Luminescence dating of quartz using an improved single-aliquot regenerative-dose protocol. Radiat Meas 32:57-73. https://doi.org/10.1016/S1350-4487(99)00253-X

Mycielska-Dowgiałło E (1993) Estimates of Late Glacial and Holocene aeolian activity in Belgium, Poland and Sweden. Boreas 22:165-170. https://doi.org/10.1111/j.1502-3885.1993.tb00177.x

Mycielska-Dowgiałło E, Woronko B (1998) Rounding and frosting analysis of quartz grains of sand fraction, and its interpretative value. Przegląd Geol 46:1275-1281 (in Polish with English abstract)

Narayana AC, Mohan R, Mishra R (2010) Morphology and surface textures of quartz grains from freshwater lakes of McLeod Island, Larsemann Hills, East Antarctica. Curr Sci 99:1420-1424

Nartišs M, Kalińska-Nartiša E (2017) An aeolian or a glaciolacustrine record? A case study from mielupite, Middle Gauja lowland, Northeast Latvia. Geologos 23(1):15-28. https://doi.org/10.1515/ logos-2017-0002

Obreht I, Zeeden C, Schulte P, Hambach U, Eckmeier E, Tima-Gabor A, Lehmkuhl F (2015) Aeolian dynamics at the Orlovat loesspaleosol sequence, northern Serbia, based on detailed textural and geochemical evidence. Aeolian Res 18:69-81. https://doi. org/10.1016/j.aeolia.2015.06.004

Ojala AEK, Saarinen T, Salonen VP (2000) Preconditions for the formation of annually laminated lake sediments in southern and central Finland. Boreal Environ Res 5:243-255

Pisarska-Jamroży M, van Loon AJ, Woronko B (2015) Sorting of heavy minerals in sediments deposited at a high accumulation rate, with examples from sandurs and an ice-marginal valley in NW Poland. GFF 137(2):126-140. https://doi.org/10.1080/11035 897.2015.1009158

Prescott JR, Stephan LG (1982) The contribution of cosmic radiation to the environmental dose for thermoluminescence dating. PACT 6:17-25

Rasmussen SO, Andersen KK, Svensson AM, Steffensen JP, Vinther BM, Clausen HB, Sigaard-Andersen M-L, Johnsen SJ, Larsen LB, Dahl-Jensen D, Bigler M, Röthlisberger R, Fischer H, GotoAzuma K, Hansson ME, Ruth U (2006) A new Greenland ice core chronology for the last glacial termination. J Geophys Res 111:D06102. https://doi.org/10.1029/2005JD006079

Ratas U, Raukas A, Rivis R, Tavast E (2015) Aeolian activity on the Northern Coast of Lake Peipsi, North-Eastern Estonia. J Coast Res 299:25-35. https://doi.org/10.2112/JCOASTRES-D-12-00231.1

Raukas A (1999) Aeolian activity. In: Miidel Avo, Raukas Anto (eds) Lake Peipsi. Geology. Sulemees Publishers, Tallinn, pp 120-124

Raukas A (2011) Evolution of aeolian landscapes in north-eastern Estonia under environmental changes. Geogr Pol 84:117-126. https://doi.org/10.7163/GPol.2011.S1.8

Raukas A, Hütt G (1988) On the luminescence dating of aeolian deposits in Estonia. Baltica 11:17-24

Raukas A, Rähni E, Miidel A (1971) Marginal glacial formations in North Estonia. Estonian Academy of Sciences, Tallinn

Rawling JE, Hanson PR, Young AR, Attig JW (2008) Late Pleistocene dune construction in the Central Sand Plain of Wisconsin, USA. Geomorphology 100:494-505. https://doi.org/10.1016/j.geomo rph.2008.01.017

Rosentau A, Hang T, Miidel A (2004) Simulation of the shorelines of glacial Lake Peipsi in Eastern Estonia during the Late Weichselian. Geol Q 48:299-307

Salamon T, Zieliński T (2010) Unusual development of sandur sedimentary succession, an example from the pleistocene of S Poland. Geologos 16:83-99. https://doi.org/10.2478/v10118-009-0007-9

Sitzia L, Bertran P, Bahain J-J, Bateman MD, Hernandez M, Garon H, de Lafontaine G, Mercier N, Leroyer Ch, Queffelec A, Voinchet P (2015) The quaternary coversands of southwest France. Quat Sci Rev 124:84-105. https://doi.org/10.1016/j.quascirev.2015.06.019

Steffensen JP, Andersen KK, Bigler M, Clausen HB, Dahl-Jensen A, Fischer H, Goto-Azuma K, Hansson M, Hohnsen SJ, Jouzel J, Masson-Delmotte V, Poop T, Rasmussen SO, Röthlisberger R, Ruth U, Stauffer B, Siggaard-Andersen M-L, Sveinbjörnsdóttir Svensson A, White JWC (2008) High-resolution Greenland ice core data show abrupt climate change happens in few years. Science 321:680-684. https://doi.org/10.1126/science.1157707

Tolksdorf JF, Kaiser K, Terberger T, Klasen N, Schneider B, Masberg P (2010) Aeolian sedimentation in the Rhine and Main area from 
the Late Glacial until the Mid-Holocene. Quat Sci J 59:36-43. https://doi.org/10.3285/eg.59.1-2.03

Tolksdorf JF, Klasen N, Hilgers A (2013) The existence of open areas during the Mesolithic: evidence from aeolian sediments in the Elbe-Jeetzel area, northern Germany. J Archaeol Sci 40:28132823. https://doi.org/10.1016/j.jas.2013.02.023

Ujházy K, Gábris G, Frechen M (2003) Ages of periods of sand movement in Hungary determined through luminescence measurements. Quat Int 111:91-100. https://doi.org/10.1016/S1040 $-6182(03) 00017-X$

Vandenberghe DAG, Derese C, Kasse C, Van den Haute P (2013) Late Weichselian (fluvio-) aeolian sediments and Holocene driftsands of the classic type locality in Twente (E Netherlands): a high-resolution dating study using optically stimulated luminescence. Quat Sci Rev 68:96-113. https://doi.org/10.1016/j.quasc irev.2013.02.009

Vassiljev J, Saarse L (2013) Timing of the Baltic Ice Lake in the eastern Baltic. Bull Geol Soc Finl 85:9-18

Veski S, Seppä H, Stančikaitė M, Zernitskaya V, Reitalu T, Gryguc G, Heinsalu A, Stivrins N, Amon L, Vassiljev J (2015) Quantitative summer and winter temperature reconstructions from pollen and chironomid data between 15 and $8 \mathrm{ka} \mathrm{BP}$ in the Baltic and Belarus area. Quat Int 388:4-11. https://doi.org/10.1016/j.quain t.2014.10.059

Woronko B, Rychel J, Karasiewicz MT, Ber A, Krzywicki T, Marks L, Pochocka-Szwarc K (2013) Heavy and light minerals as a tool for reconstructing depositional environments: an example from the Jałówka site (northern Podlasie region, NE Poland). Geologos 19:47-66. https://doi.org/10.2478/logos-2013-0004

Woronko B, Zieliński P, Sokołowski RJ (2015) Climate evolution during the Pleniglacial and Late Glacial as recorded in quartz grain morphoscopy of fluvial to aeolian successions of the European Sand Belt. Geologos 21:89-103. https://doi.org/10.1515/logos

Zeeberg J (1993) Aeolian redistribution of glacial silt and sand in Estonia and the Baltic region. Report GEOPRO 12. Utrecht University, Facutly of Geographical Sciences, Utrecht, p 67

Zeeberg J (1998) The European sand belt in eastern Europe- and comparison of Late Glacial dune orientation with GCM simulation results. Boreas 27:127-139

Zieliński P, Sokołowski RJ, Woronko B, Jankowski M, Fedorowicz S, Zaleski I, Molodkov A, Weckwerth P (2015) The depositional conditions of the fluvio-aeolian succession during the last climate minimum based on the examples from Poland and NW Ukraine. Quat Int 386:30-41. https://doi.org/10.1016/j.quaint.2014.08.013

Zieliński P, Sokołowski R, Fedorowicz S, Woronko B, Hołub B, Jankowski M, Kuc M, Tracz M (2016a) Depositional conditions on an alluvial fan at the turn of the Weichselian to the Holocenea case study in the Żmigród Basin, southwest Poland. Geologos 2:105-120. https://doi.org/10.1515/logos-2016-0012

Zieliński P, Sokołowski RJ, Woronko B, Fedorowicz S, Jankowski M, Standzikowski K (2016b) Sandy deposition in a small dry valley in the periglacial zone of the Last Glacial Maximum: a case study from the Józefów site, SE Poland. Quat Int 399:58-71. https://doi. org/10.1016/j.quaint.2015.08.089 